\title{
The Degree of Applicability of the Requirements of International Building Codes for Persons with Physical Disabilities in a Sample of Jordanian Universities
}

\author{
Alia Mohammed Saleh Al-Oweidi ${ }^{1}$ \\ ${ }^{1}$ Associated Professor in Special Education, The World Islamic Sciences and Education University \\ Correspondence: Alia Mohammed Saleh Al-Oweidi. E-mail: alia.oweidi@wise.edu.jo
}

Received: December 30, 2017

Accepted: February 20, 2018

Online Published: April 19, 2018

doi:10.5539/ass.v14n5p75

URL: https://doi.org/10.5539/ass.v14n5p75

\begin{abstract}
This study aims to identifying the degree of applicability of the international building codes requirements for persons with Physical in a sample of Jordanian universities. The study sample comprises of (53) faculties' buildings in Jordanian universities; (26) private universities and (17) Public universities.

To achieve the Purpose of this study, a scale consisting of (43) Items was used based on reliable and Valid Construction criteria codes. Results indicate that the degree of application ranges between low and average on the main dimensions of the scale, whereas it ranges between very low and high on Items.

The results also reveal no significant statically degree in the application with reference to the variable university type (Private / Government).
\end{abstract}

Keywords: international building codes, persons with physical disabilities, Jordan Universities

\section{Introduction}

Modern trends in special education seek to integrate disabled people and achieve the physical environment that are less constrain for their abilities. According to the philosophies emerges from special education, the idea of integration became more useful by eliminating all the barriers in front of those people as this is reflected positively on them and their families.

Students with physical disabilities face environment obstacle sin the university, as it hinders their access to full integration and education, though some of them are made to enable them from living independently (Paul, 2002). Providing facilities (accessibility) and removing all obstacles will help them to achieve are their goals and participate in the university life effectively (Griffin, 2004).

On the Arabic level, the field of special education is developing; however, it needs more time to address the issues of environment access for such kinds of students. As many building in the Arab world don't observe the need of disabled people to move freely and safely, this requires the activation of building codes in many Arab countries (Al-Khatib, 2013).

In Jordan, there is a concerted effort between official bodies such as the Ministry of Public Works and the Supreme Council for the Rights of Persons with Disabilities to activate building codes on the buildings and include the updated code for the requirements of residential buildings; as well as educational buildings and technical details related to public safety such as emergency areas in buildings, The supervision of the sidewalks, traffic junctions and signs for disabled persons and providing the highest levels of public safety for this category

The Jordanian code of 2017 provided in article 6 (Implementing the requirements of the national building code for persons with disabilities issued by the parties concerned on all buildings of the public and private sectors and applying this code on existing buildings wherever possible)

Before that law number 32 of 2007 in article $4(\mathrm{H})$ regarding environmental access provided that:

1. Implementing the requirements of the national building code for persons with disabilities issued by the parties concerned on all buildings of the public and private sectors and applying this code on existing buildings wherever possible.

2. Withholding building licenses to any party until verification of the commitments specified in the provisions of 
Article (1) of this Law.

3. Obligating all public transportation companies, tourism agencies and car rental companies to make available at least one vehicle with specifications that enable easy use by persons with disabilities.

4. Enabling persons with disabilities to have free access to information and communications technologies and systems including the internet, visual, printed and audio media outlets as well as emergency services including the availability of sign language translators www.hcd.gov.jo/ar.

Achieving building codes helps the integration of disabled people in the society, and it is an essential thing in their university life. This will facilitate their study and will encourage them to pursuit their academic life to be productive people in their communities (Yein, 2004; Ozkan \& Lauren, 2015).

So this study aim to Exploring the environment facilities provided for physical disabled people in Jordanian universities, Investigating the degree of applying the requirements of international building code of physical disability people in a sample of Jordanian universities and Investigating the degree applying the requirements of international building code of physical disability people in a sample of Jordanian (public/ private) universities.

\subsection{Statement of Purpose}

Environmental facilities for physically disabled people are the main element to their movement in the society and integrating in it. Therefore, to ease their move into university life they must be provided with those facilities inside the buildings, as shortage in such trend will reduce their opportunity in attending universities. Therefore, the current study is seeking to answer the following questions:

1. What is the degree of applying the requirements of international building code of physical disability people in a sample of Jordanian universities?.

2. Are there any significant statistical differences at the level of $(\alpha=0.05)$ of the degree applying the requirements of international building code of physical disability people in a sample of Jordanian universities attributed to university type ( public/private)?

\subsection{Literature Review}

Providing disabled people with environment facilities is a right granted by local and international organizations according to the laws and regulations related to the facilitation of their lives within building codes and making suitable modifications taking into consideration the type of disability.

Achieving those requirements required providing them by specialists according to the architectural characteristics suitable for disabled people. Specialists can observe the requirements of international building code while planning buildings and the must follow up with new trends and codes in America and Australia which are considered the most modern codes in the world (Jawad, 2011).

The American law of disabled people related to building code had been issued to provide them with all abilities to move inside buildings as well as using all facilities in their universities easily to enable them from using their creative potentials inside the university (Bialka, Morro, Brwon, \& Hannag, 2017). This was confirmed through Paul (2002) study that explained the role of environment facilities in the success of disable students in the university.

\subsection{The Requirements of Buildings for Physically Disabled People}

In order to fit the use of disabled people, buildings must have certain requirements, such as:

- $\quad$ Building Entrance: easy to be used and accessed.

- $\quad$ Providing slopes inside the building

- Special parks for wheel chairs.

- Suitable grounds for the move of chairs.

- Taking into account thresholds in front of entrances.

Doors:

- The doors open towards the wall.

- The doors and handles are harmless.

- Using solid floors.

- $\quad$ Providing handrails to prevent falling down. 
- $\quad$ The existence of guiding signs needed by disabled people and using known symbols with a different color from the background. (ADA Center, University of Washington, 2010).

Many studies dealt with the buildings code, for example; a study was conducted within Oroville facilities re-licensing project (2002) called for the application of the code to provide disabled people with the needed services.

Yuen (2004) Study sought to determine the extent of awareness of the architectural and interior design needs of people with physical disabilities. The study's survey instrument, which was distributed to students attending The Master's College during the spring semester, 2004, requested demographic data in addition to the responses of The Master's College are not fully aware of the architectural and interior design needs of individuals that are physically disabled. Therefore, from the information gathered from the Review of the Literature and the survey instrument, it is concluded that even though there has been an increase of accessibility in architectural and interior design, the community still does not have complete awareness of the architectural and interior design needs of individuals with physical disabilities. Al-muqani, N. (2004) conducted a study in Gaza strip to investigate the compatibility of educational institutions in Gaza strip for disabled people and the most important problems they face. The researcher reviewed the records of the ministry of education and the bases of building those institutions. The findings showed that those institutions are not qualified for physically disabled people. Further, the main requirements for disabled people such as curves and toilets are not available, however, UNRAW school are much better than public schools. And Bakri (2009) studied the compatibility degree of construction requirements code related to disabled people on building and facilities in Jordan and America. The study sample consisted of (66) buildings used by disabled people and (30) disabled persons and disabled children parents. The findings showed that there is a need to improve the application of the code and the need of using signs, handrails and other facilities. Moreover, there are problems facing environment facilities such as special parks, ladders and pavements problems as well as the lack of suitable toilets or elevators. Ali \& Salman (2014) The Aim of the current research is to study the knowledge of environmental facilities in public buildings, from the perspective of persons with disabilities in secondary school and university in different types of disability (motor, auditory and visual). In Al-Jouf, Saudi Arabia. The sample consisted of 25 students handicapped by (14) of the secondary and (11) of the Undergraduate and use the standard facilities of environmental public buildings from the point of consider persons with disabilities (for researchers). The results indicated order of facilities environmental public buildings from the viewpoint of the disabled ranged between low and high with a rate of $(50 \%-90 \%)$.

Previous studies discussed the services provided for disabled people especially environment facilities. The researcher used those studies to deepen understanding of the problem, developing the study tool and reviewing the statistical measures. The current study is different from those studies as the main aim of the study is investigating the application the requirements of international building code of physical disability people.

\section{Methodology}

Descriptive Research design (survey study) used in this study.

\subsection{Participants}

The population of the study consisted of all public and private universities in Jordan totaling (30) Universities, 10 public ones and 20 private ones. (www.Mohe.gov.jo).

A Sample of buildings were selected randomly from the faculties of (Engineering, IT and sciences) as well as (Arts, Educational sciences) in 8 private universities and 5 public ones (appendix 1)

\subsection{Instrument}

To achieve the aim of the study the researcher reviewed ADA Standards and the International Building Code and Bakri (2010) scale as well physical disability studies to develop the study instrument, the first draft of the questionnaire contained (47) items.

\section{Validity:}

The researcher validated the instrument by consulting five raters from special education colleges and engineers; the researcher followed the recommendations of the referees and made amendments accordingly. The final draft of the questionnaire contained (45) items.

\section{Reliability:}

The researcher administered it to a pilot sample of (5) buildings with the help of architecture engineers from Islamic sciences university and Balqa applied university The values of reliability were $(0.81,0.94,0.89$, 
$0.83,0.87$ ) respectively for the domains, all values are accepted for the purpose of the study.

\subsection{Study Procedures}

- $\quad$ Addressing universities, to obtain approvals.

- Applying the tool on a pilot sample in Al-Blaqa applied university and The World Islamic and Education sciences university.

- Preparing the final draft of the tool and visiting the universities.

- Training three observers with Bs degree in special education to apply the tool and writing their comments.

\subsection{Study Variables}

Independent variable: university type (public- private)

Dependent variable: performance on the building code questionnaire

\section{Scoring Results}

The scoring was as follows;

- $\quad$ means between (1-0.75) high

- $\quad(0.50-0.74)$ average

- $\quad(0.25-0.49)$ low

- Less than 0.25 very low

Percentages of frequencies on the five domains of the questionnaire were scored as follows:

- $\quad$ Higher than $80 \%$ a high application degree.

- $\quad 60 \%-79 \%$ average.

- $\quad 40 \%-50 \%$ low

- $\quad$ Less than $40 \%$ very low.

Table 1. Means and Standard deviations pf the domains of the requirements of international building codes for persons with Physical disabilities $(\mathrm{n}=45)$

\begin{tabular}{cccc}
\hline Domains & M & SD & Compatibility Degree \\
\hline Facilities Entrances & .49 & .22 & Low \\
Corridors and Internal environment & .72 & .15 & Average \\
Parks & .62 & .16 & Average \\
Elevators & .51 & .34 & Average \\
Physical Environment & .45 & .26 & Low \\
\hline
\end{tabular}

It is noted from Table (1) that the highest means were for the second domain (corridors and internal environment), while; the lowest for the fifth domain (physical environment). This can be explained by the fact that the buildings meet the requirements of the code especially steps and handrails as well as the two-side door handles.

Table 2. Frequency rates for the applicability the requirements of international building codes for persons with Physical disabilities

\begin{tabular}{|c|c|c|c|c|}
\hline & Items & Apply & $\begin{array}{l}\text { Doesn't } \\
\text { apply }\end{array}$ & Degree \\
\hline \multicolumn{5}{|c|}{ Entrances } \\
\hline 1 & The height of the college door is not least than $(1.20 \mathrm{~m})$ in minimum & 79.6 & 20.4 & high \\
\hline 2 & The entrance has an umbrella not less than $1.20 \mathrm{~m}$ & 46.3 & 53.7 & low \\
\hline 3 & The entrance has no steps & 40.7 & 59.3 & low \\
\hline 4 & There are signs to explain the services of disabled people inside the building & 31.5 & 68.5 & Very low \\
\hline \multicolumn{5}{|c|}{ Corridors and Internal environment } \\
\hline 5 & The width of the corridors is not less than 120 to facilitate the move of the chair & 81.5 & 18.5 & high \\
\hline
\end{tabular}


wheel

6 The construction material are solid and stable

7 The corridors services are non-slip, with a coarse surface

8 There are no obstacles on the head level such as bins and fire extinguishers

9 There are no-slip comfortable steps

10 There is a handrail along all steps

11 The height of the steps from the bottom is equal

12 The number of steps in each unit is not more than 10

13 There are no swing, revolver or folding doors in the building, and use doors that are easy to use and use by disabled people

14 There are no doors open outside

15 The width of doors is not less $90 \mathrm{~cm}$

16 The handles are horizontal and vertical not as revolvers

17 There are doors handles in both sides

\section{Parks}

18 There are special parks for disabled people inside the building

19 There are sings to guide disabled people in the parks

20 The park of disables people is painted specially

21 The parks services are made of solid material such as Asphalt and tiles

22 There are spaces for the move of the chair wheel within $140 \mathrm{~m}-180 \mathrm{~m}$

23 There are parks for the wheel chairs inside the building

24 There are fire alarms in the building working automatically with visual and light signs

25 The boxes used inside the building such as mail and complaint boxes are big and east to use by the disabled

26 The surface of the tiles is flat and free from any protrusions.

27 There are at least one water fountain in the building within $90 \mathrm{~cm}$ high of the tiles

\section{Elevators}

28 There are electrical elevators to ensure its stop on the needed levels

29 The width of the elevator not less than $110 \mathrm{~m}$ and deep with 140

30 The elevator is provided with audio sings to explain the floor number

31 The elevator is marked with signs indicating the movement of the elevator and the floor number

32 There are horizontal benches on the elevator walls to help the disabled to use their canes

33 The elevator can be opened manually in case of electricity failure

34 The elevator cabin has telephones and bills in case of emergency

35 The elevator hatch is not less than $1 \mathrm{~m}$

Physical Environment

36 There are rooms and toilets for disabled people

37 Toilets doors open for outside

38 The toilets doors have locks can be opened from outside

39 Faucets don't need any efforts to be opened

40 The disabled person can move from one building to another easily

41 Teaching halls are provided with special arrangements for disabled people such as the width of rows

$83.3 \quad 16.7 \quad$ high

$53.7 \quad 46.3 \quad$ low

$57.4 \quad 42.6 \quad$ low

$48.1 \quad 51.9 \quad$ low

$92.6 \quad 7.4 \quad$ high

$85.2 \quad 14.8 \quad$ High

$\begin{array}{lll}46.3 & 53.7 \quad \text { Low }\end{array}$

$68.5 \quad 31.5$

$64.8 \quad 35.2 \quad$ Average

$77.8 \quad 22.2 \quad$ Average

$98.1 \quad 1.9 \quad$ High

$90.7 \quad 9.3 \quad$ High

$\begin{array}{lll}33.3 & 66.7 & \text { Very low }\end{array}$

$24.1 \quad 75.9 \quad$ Very low

$16.7 \quad 83.3 \quad$ Very low

$63 \quad 37 \quad$ Average

$61.1 \quad 38.9 \quad$ Average

$29.6 \quad 70.4 \quad$ Low

Average

$74.1 \quad 25.9$

low

$42.6 \quad 57.4$

$81.5 \quad 18.5 \quad$ High

$44.4 \quad 55.6 \quad$ low

$84.8 \quad 15.2 \quad$ high

$57.4 \quad 42.9 \quad$ Average

$44.4 \quad 55.6 \quad$ low

Average

$66.7 \quad 33.3$

$51.9 \quad 48.1$

$25.9 \quad 48.1$

$59.3 \quad 40.7$

low

42 There are facilities un using public services such as restaurants and phones

$80.3 \quad 19.7$

Very low

low

high

$\begin{array}{lll}46.3 & 53.7 \quad \text { low }\end{array}$

$38.9 \quad 61.1 \quad$ Very low

$53.7 \quad 46.3 \quad$ low

$90.7 \quad 9.7 \quad$ high

$44.4 \quad 75.9 \quad$ low

low

$44.4 \quad 75.9$

$55.6 \quad 44.4 \quad$ low

The findings of Table (2) showed that the requirements of building code are applied in a high degree in some items such as the height of the college entrance, the width of corridors. Further, the materials used are strong and solid and there are handrails on steps. All the doors handles are suitable for disabled people and the level of tiles too.

Moreover, the findings showed that the applying degree for most of the items is in an average level, such as the 
difficulty in opening doors, the mechanism of fire alarms and some problems on elevators in some universities.

There are low results in some items, such as the umbrellas in some universities, the soft surfaces and the slippery character to steps as well as the big boxes that beyond the reach of the disabled person.

The height of water sinks is more than $90 \mathrm{~cm}$ from the tiles, and the elevators have no special signs for disabled people, especially horizontal handles. Toilets can't be opened from outside and the physical environment doesn't facilitate the move of the disabled person from one building to another.

The findings showed that those services are not available for the disabled person inside the building, such as, guiding sings in the parks, and the parks have no special painting for the disabled people.

This can be explained by the fact that some universities think that applying this code will be a financial burden, in addition to the low rate of disabled people in public universities. Moreover, this van be due to the old construction of the buildings, therefore, the building code is not applied. Another reasons is the weak legislations that don't oblige universities to observe the building code while building their facilities.

These findings are in consistent with (Yein, 2012) study that concluded that there is a shortage in the architecture designs of disabled people. In addition, Estes (2004) concluded that multi-disability students need a special environment in their colleges. In a study conducted in Jordan Bakri (2012) provided that public buildings in Jordan met the requirements of the building code.

However, the current study differs from (Ali \& Suleiman, 2014) findings that indicated the high degree of applying the code in environment facilities.

Table 3. Means, Standard deviations and t-test for the university type variable (private-public) on the applicability degree for the requirements of international building codes $(\mathrm{n}=53)$

\begin{tabular}{ccccccc}
\hline & type & No & $\mathrm{M}$ & $\mathrm{SD}$ & $\mathrm{T}$ & sig \\
\hline \multirow{2}{*}{ Entrances } & private & 36 & 0.5 & 0.18898 & 0.813 & 0.12 \\
& public & 17 & 0.5147 & 0.27201 & & \\
& private & 36 & 0.745726 & 0.1622115 & 0.285 & 0.596 \\
Corridors and Internal Environment & public & 17 & 0.701357 & 0.1461598 & & \\
& private & 36 & 0.629452 & 0.1501156 & 0.791 & 0.378 \\
& public & 17 & 0.61991 & 0.1784182 & & \\
Elevators & private & 36 & 0.561728 & 0.3284773 & 2.335 & 0.133 \\
& public & 17 & 0.424837 & 0.3873686 & & \\
& private & 36 & 0.503086 & 0.2484323 & 0.053 & 0.82 \\
& public & 17 & 0.385621 & 0.2753159 & & \\
\hline
\end{tabular}

Table (3) shows that there are no significant statistical differences on the degree of international code buildings standards of disabled people in both public and private universities, this means that public and private universities don't take into consideration this code and this is an obstacle in front of disable people. This may be attributed to the construction process which was conducted before obtaining this code.

\section{Conclusion}

Activating the supervisory role through applying the disabled code of 2017 which provided the necessity of considering applying building code in buildings. Also universities need to Re- carrying out the building code of disabled people inside the colleges that didn't consider it yet, and obliging the ministry of higher education to provide the environment facilities through applying the building code on the building of the university faculties. More research need to Conduct a study to investigate the obstacles facing higher education institutions in applying the requirements of international code building of disabled people .

\section{References}

Accessibility Checklist Oregon. (2010). Ada Standards for Accessible Design Oregon State Building Code. October 2013. Northwest ADA Center, University of Washington.

Ali, A., \& Salman, R. (2014). Environment facilities in Public buildings as perceived by the disabled in Secondary and University Stages. Journal of Studies in Education and Psychology, 45(2), 179-197. 
Al-khatib, J. (2013). Introduction to Physical and health disability. Amman: Al-shrouq Publishers.

Al-mihiri, O., Abdat, R., Al-sartawi, A., \& Taha, B. (2015). The compatibility of public and private schools of Integrative Classes in Abu Dhabi Province. Special Education Journal, 2(6), 1-26.

Al-muqani, N. (2004). The compatibility of educational institutions in Gaza Strip for the needs of disabled people. Research. Aqsa University.

Bakri, Y. (2009). Comparative Study between the building code of disabled in Jordan and America and the applicability of the Jordanian code on buildings and related problems ( $\mathrm{PhD}$ dissertation). Jordan University. Jordan.

Bialka, C. H., Morro, D., Brownm, K., \& Hannah, G. (2017). Breaking Barriers and Building Bridges: Understanding How a Student Organization Attends to the Social Integration of College Students with Disabilities. Journal of Postsecondary Education and Disability, 30(2), 157-172.

Building Handbook ACCESS. (2014). Illustrated Commentary on Access Requirements in the British Columbia Building Code 2012. National Library of Canada Cataloguing in Publication Data Main entry under title.

Cullen, M. (2006). Improving Transport Accessibilities for All. Guide to Good Practice. France: OECD Publications

Griffin, K. (2004). Building Type Basic for Transit Facilities. Hopoken, NJ: John Wily \& Sons.

Jawad, N. (2011). Engineering Analysis: The Cost Variation of Buildings Adaptation to Disabled People in the Gaza Strip. Al-Aqsa Unv., 15(1).

Ozkan, T., \& Lauren, L. (2015). Accessibility of Accommodation Facilities for Individuals with Disabilities. Palaestra, 29(4), 1-25.

Paul, S. (2002). Students with Disabilities in Higher Education: A Review of the Literature. Collage Student Journal, 34(2). 200-210.

Yuen, O. (2004). Awareness of the Architectural and interior design needs individuals with physical Disabilities. URE recourses. The Masters Collage.

\section{Copyrights}

Copyright for this article is retained by the author(s), with first publication rights granted to the journal.

This is an open-access article distributed under the terms and conditions of the Creative Commons Attribution license (http://creativecommons.org/licenses/by/4.0/). 